\section{ENTREPRENEURSHIP AS A CONSEQUENCE OF EXTERNAL STIMULI AND/OR INTERNAL INCENTIVES}

\section{Bobera Dušan}

University of Novi Sad, Faculty of Economics Subotica, Serbia

$\triangle$ bobera@ef.uns.ac.rs

\section{Slobodan Marić}

University of Novi Sad, Faculty of Economics Subotica, Serbia

$\bowtie$ marics@ef.uns.ac.rs

\section{Bojan Leković}

University of Novi Sad, Faculty of Economics Subotica, Serbia $\triangle$ bojan.lekovic@ef.uns.ac.rs

UDC

005.961:

005.914 .3

Original

scientific paper

Received:

15.10.2014

Accepted:

27.03.2015

\begin{abstract}
The basic goal of this work is the cognition of fundamental entrepreneurial motives (necessity and opportunity) depending on general social and entrepreneurial opportunities according to the stages of entrepreneurial process. The work presents the results of the analysis of selected variables previously cited appearances based on data from the GEM project in 2009 for 48 countries classified into three groups according to the stages of economic development. To compare groups and establish differences, one-factor analysis of variance was used, while relationships and connections between selected features of development degrees, entrepreneurial activities and motives of entrepreneurial projects were analyzed by the Pearson correlation coefficient. The analysis of available data and selected features confirmed a great dependence of motives of entrepreneurial projects and conditions of the environment of different development degrees that determine differences to all observed features directly or indirectly connected with entrepreneurial decisions.
\end{abstract}

Keywords: entrepreneurship, entrepreneurial process, entrepreneurial conditions, necessity entrepreneurship, opportunity entrepreneurship 


\section{Introduction}

In the analysis of available literature and ruling attitudes within the framework of previous and current research, we opposed two types of entrepreneurs, i.e. entrepreneurs who start business and whose attitudes, intentions and activities are extorted by current economic circumstances, necessity entrepreneurs contrary to entrepreneurs who recognize market possibilities as potential for creating new values or realizing personal ambitions in the form of change of the way of life as opportunity entrepreneurs. The basic difference between the socalled necessary entrepreneurs and entrepreneurs-opportunists is seen in the motive of starting business; it is the basis point of this work. The principal attempts are oriented towards the analysis of prevailing motives in some stages of the entrepreneurial process depending on the attained degree of economic development as a determinant of entrepreneurial conditions. Further, the analysis tries to establish potential differences between different degrees of economic development of countries classified into three groups according to the methodology of the World Economic Forum known in advance, according to selected variables which directly or indirectly point to the motives of entrepreneurial projects. The last segment of the quantitative analysis relates to examining the relationships and variables that directly demonstrate the motives of the entrepreneurial project with variables which are indirectly connected with the fundamental motives of entrepreneurial behavior.

The central research aim and key problem orientation as a basic intention of this work is to answer the question on how much system circumstances in the form of attained degree of economic development and, in accordance with the current specific entrepreneurial circumstances, form the motives of entrepreneurial behavior, on the one side, and entrepreneurial circumstances as elements of the overall social environment, on the other side.

In the study there is a set following objectives:

- Identify differences between two types of entrepreneurship, necessity and opportunity;

- Impact economic condition on entrepreneurial behavior as a necessity and opportunity entrepreneurs;

- Dominant motive of entrepreneurial behavior.

The research methodology involves the use of parametric procedures due to the characteristics of the selected variables and the number of observations in the sample. The anivariate ANOVA procedures and Pearson's coefficient correlation will be used. The application of the chosen methodology is aimed to determine the characteristics of each subsample (group of countries) potential differences and boundaries in order to make appropriate conclusions. The basis of this study consists of data for selected variables from Database of the GEM 
project and World Economic Outlook Database. The novelty of this study is identified the main motive entrepreneurship irrespective of the degree of economic development.

The rest of work is outlined in four parts. The second part points to the motives of entrepreneurial behavior. The third part illustrates the methodology and sources of data processed by statistical procedures. In addition, in this part, selected indicators as research variables are specially represented. The fourth part comments the results carried out by statistical analysis, while the fifth part is reserved for conclusions.

\section{Motives of Entrepreneurial behavior - Incentives of an Individual or the Stimuli of the environment?}

Motives as the entries of human behavior or motivation factors as determinants of individual behavior are basic reasons because somebody is ready to change and orient his/her attitudes, intentions and activities what, in any case, is valid with entrepreneurs. If we try to explain basic sources of motivation factors by Maslow's basic motivation theory (1954), then we come to the answer named the unsatisfied needs of a human. Therefore, the individual shows the level of satisfied needs with readiness to undertake some activities, but also through his/her whole behavior as a complex indicator of realized targets and future intentions. The generally accepted indicator of the standard of living, i.e. the quality of life of individuals, and attained degree of economic development of a country, too, is of course GDP (Gross Domestic Product) per capita in US\$, taking into consideration the relative values of purchasing power parity basis. This macroeconomic indicator was the key entry for grouping of countries in three stages of economic development, according to the WEF methodology (World Economic Forum) ${ }^{1}$. This correction enables comparison of national economies at the global level starting from the same basis. Quality of life of individuals expressed in GDP per capita does not represent only he reached level of material basis but it is the expression of social, economic, political and cultural conditions that form individual behavior, determines possibilities and needs, as well as sort and intensity of influences on the future development flows relating to attained capabilities to realize some activities, actually in the field of entrepreneurship. Countries of different development level, measured and illustrated by this indicator, show different capacities for entrepreneurial behavior regarding to the volume and kind of entrepreneurial activities, but different motives for taking it over, too.

Levi and Autio (2008), within the framework of the GEM study set the conceptual framework of entrepreneurial and generally economic environment, establishing mutual relationships and connection with some forms of

\footnotetext{
${ }^{1}$ Explained in details in GCI (Global Comprehensiveness Report 2009 - 2010, (Schwab, 2009)
} 
entrepreneurial activities, treating the environment as fundamental source of initial impulses of entrepreneurial behavior. This conceptual model of entrepreneurial environment has the base completely and it is supported by the standpoints of the classical Austrian economic school in all its segments. It is indisputable that Schumpeter was the first economist to connect entrepreneurs with economic flows and who rejected of the prevailing approach of comparative statistics and recognized economics as self-transforming system with an entrepreneur as the agent of changes (Schumpeter, 1934). Schumpeter represents entrepreneurs as innovators who create conditions to acquire profit by creating a contemporary monopoly by means of organizational and technological innovations. By their activities, they constantly disturb the current state of balance preferred by existing business actors forcing them to react to newly appeared threats. This process of 'creative destruction' (Schumpeter, 1947 ) is manifested in improving productivity, as well as higher economic growth. This approach is advanced and developed further by Baumola (2002) and Acsa (2004) who was the last to develop a new growth theory with the explicit role of the Schumpeter entrepreneur as transformer of knowledge in economic knowledge and a significant participant of economic growth. As we have already said, the Schumpeter entrepreneur disturbs the state of economic balance through the process of innovations, while the alternative observation of entrepreneurs and economic growth came from the other part of Austrian economists as Ludwig von Mises (1949) and Kirzner (1997) who emphasize the role of entrepreneur as the inventor of favorable market conditions, citing 'in every real and life economy, every entrepreneur is always entrepreneur' (Mises, 1949, Kirzner 1997) similar to Schumpeter, Leibenstein (1968) identifies two basic kinds of business activities that participate in economic ticks: routine entrepreneurship or management include activities connected with coordination and management of existing business systems. New activities or nascent entrepreneurship understands activities necessary to create or transfer enterprises to markets that have not existed up to now or have not been clearly defined. Draker (1985) also accepts the previous standpoints and he does not try to belittle the importance of entrepreneurship as meta-economic event. In his opinion, some other forms of innovation should be considered as entrepreneurial ones, as it happens sometimes that an original innovator can make some mistakes that can be identified and removed with entering the market by some other participants. This type of innovation is called the 'creative imitation'. Draker's wide view on entrepreneurship has been largely accepted in the last 30 years by majority of management theorists. It is now recognized as a critical factor which determines the long-term strategic success in competition with other organizations and it is reflected in capabilities of the enterprise to be more innovative, more flexible and capable to answer fast market changes. 
The existing model (Levi and Autio, 2008) consider that new business activities are undertaken by those who believe that they have skills, knowledge and motivation to start business projects by recognizing necessary conditions. It is emphasized that starting business skills are not sufficient. Individuals must recognized possibilities before undertaking any activities. Factors exerting influence on business activities in the general sense as formal education are represented in the model within the framework of general national business conditions (institutions, infrastructure, macroeconomic stability, primary and university education, efficiency and market size, availability of technology) while those factors that make a specific framework of entrepreneurial activities, as entrepreneur training are represented as entrepreneurial conceptual conditions (government policy, programs, financing, market openness). The previous model emphasizes general entrepreneurial conditions exerting direct influence on generating the volume and nature of entrepreneurial activities. Therefore, economic ambient determines business opportunities for entrepreneurs and small business which can be exploited (Davidson, 1989). Economic governance during transition is an innovative process: it is impossible to follow a uniform approach or to use the same growth model in order to achieve the same results (Starkevičiute, 2011). All this can be an advantage in defining economic circumstances of small enterprises and entrepreneurial projects in different dimensions that are the consequences of subjective perception of small business owners. They include heterogeneity, enmity, dynamism, structure of consumers and competition (Pelham and Wilson, 1995). The dynamism of the environment is characterized by instability and continuity of changes where growth possibility appears as a consequence of social, political, technological and economic changes. Hostile environment is a generator of danger for the enterprise through competition development or demand decrease for products of the enterprise and it will significantly lessen the possibility of growth for a small enterprise. Heterogeneity of the environment means their complexity regarding to the existence of different market segments with different characteristics and needs within the same economic branch. However, heterogeneous markets are more acceptable for small business with a view of finding and developing specific market niches in relation to markets where demand is homogeneous. Dynamism and changes of the entrepreneurial context enable entrepreneur's significant advantages where, for their flexibility, they adapt better than large business systems so turning potential threats into business opportunities. Entrepreneurial projects with their continual starting and bankruptcy create imbalance for the state of disequilibrium where they better cope with and compete successfully in some situations with some bigger and stronger than they are. To some economists (Schumpeter), the shortage of entrepreneurial activities and, innovation before all, are the basic causes of economic crises. The current economic crisis, recognizable as the Global economic recession (2008), as well as all other critical conditions can represent 
stimulating circumstances for creating and developing entrepreneurial projects because, in the process of big market oscillations, new business possibilities appear in the form of new markets and available sectors. This crisis has certainly contributed to closing many enterprises and the failure of many entrepreneurial projects, reducing business size, profit and the increase of unemployment, but conditions on the labor market become the main determinant of entrepreneurial, higher unemployment rate, as one of the indicators of entrepreneurship, stimulated opening new jobs through the process of self-employment and starting new business projects (Fairlie, 2011). The relationship between the environment and entrepreneurial strategies suggest that entrepreneurial environment can be recognized, according the characteristics as dynamism, heterogeneity and enmity which can exert influence on entrepreneurial perception which can induce entrepreneurs to adapt some strategic orientation to innovation, proactivity and risk taking (Tan, 1996). Most innovations appeared in the period of depression when societies are more open for changes. Therefore, entrepreneurship represents the leading indicator of economic cycles (Schumpeter); it is suggested that entrepreneurship is not independent from economic trends (GEM Report 2010). Together with this, it is necessary to make three groups of economic-system conditions, represented in the GEM theoretical entrepreneurship model, and the degree of economic development of the country and the WEF classification according to the global competition index and it largely changes the relative importance of some groups of economic-system conditions, as well as their influence on entrepreneurial activities (Porter and Schwab, 2008). According to the previously cited authors, it means that in the countries with the lowest degree of economic development and whose activities is dominantly oriented towards the exploitation of natural resources, it is necessary to direct the main focus to the improvement of basic conditions of economic development as the government stability, infrastructure, primary education and health care. The enhancement of total competitive ability in the transitional economies requests the creation of a modern knowledgebased economy, the sustainable economic growth and the enlargement of the country's economic competitiveness (Buracas, at al., 2012).The fact definitely point to that entrepreneurial education has its first traces in highly developed countries (WEF, GCR, Innovation - driven countries), where the first evaluations of effects of entrepreneurial courses were describes by Shigeru of Cobe University, Japan in 1938 (Solomon et al., 2002) and Myles at Harvard Business School in 1947 (Katz, 2003).

For starting projects, human capital of entrepreneurs, reported in the form of its education, experience and skills represents a very significant initial resource (Wright et al., 2007). Education increases cognitive possibilities of individuals training them to find better business opportunities (Parker, 2006). Shane and Venkataraman (2000) consider that capabilities of individuals to find out business possibilities depend on having primary information necessary to identify 
possibilities and necessary cognitive characteristics to evaluate them. Primary information represent, firstly, experience based on understanding users' needs in the given region. Cognitive characteristics represent an individual's capabilities to translate information from the social interaction into the concrete market position, i.e. to transform language of supply and demand in business . The cognition of possibilities represents the key condition of entrepreneurial projects (Corbet, 2005). Schumpeter (1947) explains further the difference between an entrepreneur and an inventor considering that the entrepreneur makes things finished. As previously mentioned, it requires a special set of skills, as well as somebody that is recognized to his/her many-sided nature. Entrepreneurs need to know not only their own technical fields but also to possess a wider set of skills in the domain of business management in order to be able to evaluate the possibilities and to mobilize resources to start and new project growth. Successful management and activity organization in different fields require from the entrepreneur the role of an erudite that combines both fields, special and general management skills (Lazear, 2005). In accordance with most literature in the field of entrepreneurship pedagogy, we can state that the wide set of features builds a different aspect of the entrepreneurial process and possessing entrepreneurial characteristics represents a significant determinant of allocation, entrepreneurial efforts (Boyd and Vozikis, 1994). This profile of the erudite makes an entrepreneur as a significant demand for education and training, immediately after new entrepreneurs (Levie, 2006). Most education programs, mostly in the field of university education, try to focus on individual technical fields or making experts in the field (Bertrand, 1995). Many researchers in the field of entrepreneurial skills and training point to that highly specialized education programs are inappropriate to provide wide foundations and practical orientation of training for the needs of entrepreneurial skills (Aronsson, 2004). Instead of acquiring specialist entrepreneurial skills, the programs of training are oriented towards the increase of entrepreneurial capacities necessary for the high level of practical orientation. It relates to the wide set of managerial, leader and organization skills, acquiring cognitive possibilities and situation approach to business planning (Levie, 2006). While most necessary general skills is mostly acquired in the course of formal programs in career development and mostly because of the aspect of entrepreneurial skills, providing entrepreneurial training and instructions within education institutions will increase entrepreneurial skills. It will make every individual more efficient in finding out entrepreneurial possibilities. Many studies dealing with education in the field of entrepreneurship point to the existence of differences between entrepreneurship education and training depending on the degree of economic development of the country. It also points to the influence, finally, on training in starting business projects and entrepreneurial awareness, attitudes, attempts and activities. Therefore, many governments in highly developed countries emphasized the obligation that entrepreneurship education should be identified as the key priority (Sorgman and Parkinson, 2008). 
Taking into consideration the previously cited motivation theory and the attained degree of a country's development, we can speak about the different degree of satisfying the needs of individuals, as well as the needs that have not been satisfied so it represents the basic driving force and the motive for realizing different forms of entrepreneurial projects. As for the motive for starting the entrepreneurial project, we differentiate two basic kinds of entrepreneurs named necessity and opportunity. Support to the concept of necessity and opportunity entrepreneurship was given by many researchers in the field of entrepreneurship (Gurtoo and Williams, 2009, Hessels et al., 2008). The importance and role of this concept were recognized by the Global Entrepreneurship Monitor (GEM). The results of research in the field of necessity and opportunity entrepreneurship are classified in the final GEM reports 2002. The difference between the two groups of entrepreneurs is the motive for starting entrepreneurial projects. Necessity entrepreneurs are the people who started entrepreneurial projects for necessity, while, contrary to this, opportunity entrepreneurs are led by profitable exploitation of noticed chances. Therefore, it is visible that necessity entrepreneurs possess less human and financial capital (Caliendo and Kritikos, 2009) and it leads to the development of business project of weaker quality, with less investment and human capital so it exerts influence on the lower level of earnings, i.e. profit (Preisendorfer and Vos, 1990). Previously cited facts are confirmed by the research stated hypothesis that carried out by Block and Wagner (2010) within which the authors confirmed the opportunity entrepreneurs pursue on average more profitable opportunities than necessity entrepreneurs, that is they report higher earnings. Besides, they confirmed in their research that necessity entrepreneurs lack specific human capital and it represents the main cause of the high rate of failure in starting business projects. There are a lot of authors who have paid attention to necessity and opportunity entrepreneurs. Giacomin et al. (2011) tried to identify the impact of the socioeconomic characteristics of entrepreneurs on their opportunity-necessity positioning. Based on a sample of 538 entrepreneurs, they point out that individuals who get involved in an entrepreneurial process, have encountered a situation of necessity and/or opportunity and that the latter can take various forms. Deli (2011) in her research analyzed the effects of local unemployment rates on the propensity of low-ability (necessity entrepreneurs) and high-ability workers (opportunity entrepreneurs) to transition into self-employment. The results show a positive correlation between local unemployment rates and entry into self-employment for low-ability workers, but not for high-ability workers. Robichaud et al. (2010) tried to investigate the personal and organizational characteristics of Canadian necessity- and opportunity driven entrepreneurs and assess the influence of gender on the necessity/opportunity motivational categories. The results of the research showed that in terms of personal characteristics, the necessity entrepreneurs tended to be older, less educated, lacking in skills and 
with a lower propensity to foresee future business opportunities. The opportunity entrepreneurs tended to report higher business income. Block and Sandner (2006) with data from the German Socioeconomic Panel Study (GSOEP) analyze whether necessity entrepreneurs differ from opportunity entrepreneurs in terms of self-employment duration. Using univariate statistics, they found that opportunity entrepreneurs remain in self-employment longer than necessity entrepreneurs. The same, the crisis conditions have a double influence on starting new entrepreneurial projects. On the one side, the negative influence on necessity entrepreneurs is certain because of reducing profitability in exploiting good ideas (Thomson, 2011). On the other side, as a consequence of the fall of economic activities, the increase of number of necessity entrepreneurs appears who, because of the loss of jobs and the shortage of new jobs, start their entrepreneurial projects Blanchflower and Meyer, 1994).

Seen from the aspect of success, the motives of entrepreneurial activities contribute to significant differences. Owners of small business, stimulated and pulled in self-employment, have bigger chances to attain success than entrepreneurs pushed in it in the form of the last possibility. Therefore, a positive motivation to start business projects influences positively on performance, while individuals that consider self-employment as the last resort will be less successful (Van Praag, 1996, Van Praag and Cramer, 2001).

\section{Data and Methodology}

\section{Data and Observed Features}

The basic data source of analyzed variables in the work represent the results of the GEM project in 2009. The criterion for choice of countries was the availability of data for every country per selected variables, i.e. countries participants in the GEM project in 2009. The countries were grouped in three stages of economic development according to the WEF methodology, as explained in GCI (Global Competitiveness Report 2009 - 2010; Schwab, 2009) according to the Factor - driven economies as countries of the lowest development degree, Efficiency - driven economies as the countries of the medium development degree and Innovation - driven economies as the group of the most developed countries. The source of data for the features of economic development degree are International Monetary Fund, World Economic Database, October, 2010.

To satisfy research intentions, the following features were selected, which would represent observed appearances. The category variable of group of countries classified towards the WEF methodology (COUNTRY GROUP GCR REPORT 2009-2010 - 3 CAT) is used for the development degree, as well as GDP per capita in US\$ on PPP Basis. The volume and structure of 
entrepreneurial activities per the grades of entrepreneurial process is represented by variables of Suboan09 (\% 18-64 pop [7/09] START-UP/NASCENT (SU): active past year, (part) owner, no wages yet), Babybu09 (\% 18-64 pop [7/09] BABY BUS OWNER (BB): owns-manages business with income $<3.5$ years), TEA09 (\% 18-64 pop [7/09] TEA involvement: setting up firm or owner of young firm (SU or BB)) and Estbbu09 (\% 18-64 pop [7/09] ESTABL BUS OWNER (EB): owns-manages business with income $>3.5$ years), while the motives of entrepreneurial project were reported in direct variablesTEA09opp ( $\%$ 18-64 pop [7/09] TEA and Opportunity motive), TEA09nec (\% 18-64 pop [7/09] TEA and Necessity motive (entr because of no better choice for work)), raciooppnec (Ratio opportunity/necessity), TEA09MT4 (\% within TEA [7/09] Non-opportunity motive: necessity/maintain income) i TEA09ido (\% 18-64 pop [7/09] TEA and Improvement Driven Opportunity motive). To research the influence and analysis of prevailing motives of entrepreneurial projects, features as failure are included DISCct09 (COUNT [7/09] respondents who discontinued business (sample)), Disent09 (\% 18-64 pop [7/09] YES: Exited a business in past year, business did not continue), then the features of the working status Tea09WS1 (\% 18-64 pop [7/09] Working: \% involved in TEA), Tea09WS2 (\% 18-64 pop [7/09] Not working: \% involved in TEA), as well as the degree of education in some stages of entrepreneurial relationship TEA09ed4 (\% 18-64 pop [7/09] graduate experience: \% involved in TEA), EB_09ed4 (\% 18-64 pop [7/09] graduate experience: \% involved in EB), and it can be of importance in the form of some indication of the prevailing motives of entrepreneurial projects.

\section{Hypotheses of Researching}

The first analysis segment of available data for observing the features is oriented towards the prevailing motive of entrepreneurial behavior per stages of the entrepreneurial process depending on the degree of economic development of national economies. The first hypothesis is as follows:

H1, there is a negative correlation connection between the ratio opportunity/necessity entrepreneurship and the volume of entrepreneurial activities according to the stages of entrepreneurial process.

Taking into consideration the previously confirmed negative connection between the volume of entrepreneurial activities and the degree of economic development of countries, the derived hypothesis is imposed:

H1a, in the form of positive correlation of the ratio opportunity/necessity entrepreneurship and the degree of economic development of countries measured by GDP per capita in US\$ PPP basis.

The second segment of the analysis is oriented towards economic-system conditions of the environment, i.e. at the stage of favorableness of specific 
entrepreneurial context expressed in three stages of economic development according to the specification of WEF methodology. The aim is to represent the measure in which the economic environment of different degree of development can shape the motives of entrepreneurial behavior, as well as the secondary appearances which can be directly or indirectly connect with entrepreneurial stimuli. As a contribution to this analysis, we define this hypothesis:

$\mathrm{H} 2$, there is a statisticaly significant difference between defined groups of countries of different development degree according to all observed variables;

The last segment of the analysis deals with the relationship of motives of entrepeneurial projects of following variables that can be of significant influence on shaping entrepreneurial decisions. Expectations in this segment are expressed by the hypothesis:

H3, there is a positive correlation between the ratio opportunity/necessity entrepreneurship of high educated entrepreneurs and the entrepreneurs who, working/active at work/being already employed, entered the entrepreneurial relationship.

Contrary to this, as negative powers of opportunity entrepreneurship, we are expecting not working/inactive at work/unemployed individuals, of lower degree of education, as well as the higher rate of failure.

\section{Analysis of the Research Results and Discussion}

As the result of the analysis relating to prevailing motive of entrepreneurial behavior, represented by the variable ratio opportunity/necessity, according to the stages of entrepreneurial process and the degree of economic development, measured by GDP per capita in USD Purchasing Parity Power Basis, we got the correlation matrix represented in Table 1. From the analysis of received results, we can draw a conclusion, relating to indicators of the motives of entrepreneurial behavior, that the ration indicator is more informative and reflects concrete relations to opposed variables. It is expected that the indicators of opportunity motives and negative motives are in the negative, in this case, in a strong correlation to the degree of economic development, being that the whole entrepreneurial activity is in the same relation. The substance of nature and the strength of correlation are reflected by the ration indicators, as it represents the relationship opportunity and necessity motives of entrepreneurial behavior, showing how many times opportunity motive is prevailing. In this way, a strong positive correlation between ration opp/nec and GDP per capita in USD (PPP Basis) is identified, on what the coefficient of Pearson's correlation $r+677$ points to and a very high determination coefficient of $45 \%$. It means that in highly developed countries, there is a high level of opportunity entrepreneurship with a very low level of necessity entrepreneurship, i.e. in the overall entrepreneurial activity; opportunity entrepreneurship is prevailing in highly developed countries. 
Table 1. Correlation of Motives of Entrepreneurial Ventures and Entrepreneurial Conditions and the Phase of Entrepreneurial Processes

\begin{tabular}{|c|c|c|c|c|}
\hline & & $\begin{array}{l}\text { TEA and } \\
\text { Opportunity } \\
\text { motive }\end{array}$ & $\begin{array}{c}\text { TEA and } \\
\text { Necessity motive }\end{array}$ & $\begin{array}{l}\text { Ratio } \\
\text { opp/nec }\end{array}$ \\
\hline \multirow{3}{*}{$\begin{array}{l}\text { GDP per Capita in USD } \\
\text { Purchasing Power Parity } \\
\text { Basis }\end{array}$} & Pearson Correlation &,$- 472^{* *}$ &,$- 634^{* *}$ & $677^{* *}$ \\
\hline & Sig. (2-tailed) & 001 &, 000 &, 000 \\
\hline & $\mathrm{N}$ & 48 & 48 & 48 \\
\hline \multirow{3}{*}{$\begin{array}{l}\text { START-UP/NASCENT } \\
\text { (SU): active past year, (part) } \\
\text { owner, no wages yet }\end{array}$} & Pearson Correlation &, $928^{* *}$ &, $740^{* *}$ &,- 268 \\
\hline & Sig. (2-tailed) &, 000 & 000 & ,066 \\
\hline & $\mathrm{N}$ & 48 & 48 & 48 \\
\hline \multirow{3}{*}{$\begin{array}{l}\text { BABY BUS OWNER (BB): } \\
\text { owns-manages business with } \\
\text { income }<3.5 \text { years }\end{array}$} & Pearson Correlation &, $821^{* *}$ &, $893^{* *}$ &,$- 291^{*}$ \\
\hline & Sig. (2-tailed) &, 000 &, 000 &, 045 \\
\hline & $\mathrm{N}$ & 48 & 48 & 48 \\
\hline \multirow{3}{*}{$\begin{array}{l}\text { TEA involvement: setting up } \\
\text { firm or owner of young firm } \\
\text { (SU or BB) }\end{array}$} & Pearson Correlation &, $964^{* *}$ &, $905^{* *}$ &,$- 314^{*}$ \\
\hline & Sig. (2-tailed) &, 000 &, 000 & 029 \\
\hline & $\mathrm{N}$ & 48 & 48 & 48 \\
\hline \multirow{3}{*}{$\begin{array}{l}\text { ESTABL BUS OWNER } \\
\text { (EB): owns-manages } \\
\text { business with income }>3.5 \\
\text { years }\end{array}$} & Pearson Correlation &, $583^{* *}$ &, $713^{* *}$ &,- 230 \\
\hline & Sig. (2-tailed) &, 000 &, 000 &, 116 \\
\hline & $\mathrm{N}$ & 48 & 48 & 48 \\
\hline \multicolumn{5}{|c|}{ **. Correlation is significant at the 0.01 level (2-tailed). } \\
\hline \multicolumn{5}{|c|}{ *. Correlation is significant at the 0.05 level (2-tailed). } \\
\hline
\end{tabular}

Source: Calculation of authors

Considering the relationship of the cited ration and the size of entrepreneurial activities according to the stages of entrepreneurial processes, we can draw a conclusion that the correlation is negative at the level of weak and medium-strong one with statistical characteristics with activities BABY BUS OWNER (BB): owns-manages business with income $<3.5$ years, $r=-.291$, $\mathrm{p}=0.045$ and with non-important determination coefficient, while for TEA involvement: setting up firm or owner of young firm (SU or BB) $r=-.314$, $p=0.029$. It means that the high size of entrepreneurial activities to all the stages of entrepreneurial processes is followed by the medium-low level of ratio indicator, i.e. opportunity in relation to necessity is medium prevailing. By this analysis, we can draw a conclusion that hypotheses $H 1$ and $H 1 a$ are confirmed, which are connected with the prevailing motive of entrepreneurial behavior, according to the stages of the entrepreneurial process depending on the degree of economic development of national economy.

To emphasize the influence and power of the economic-system environment relating to shaping entrepreneurial motives, the second/another segment of the analysis. The result of risk determination between defined groups of countries 
for selected characteristics by means of one-factor variance analysis is illustrated in Table 2. Surveying the result of statistical characteristics of observed features, we can notice that the influence of environmental conditions is expressed in three groups of countries of different development stages in selected features, except in the last two, Graduate experience: \% involved in TEA and Graduate experience: \% involved in EB.

Table 2. ANOVA of Selected Features for Defining the Groups of Countries

\begin{tabular}{|c|c|c|c|c|c|c|}
\hline & & Zbir kvadrata & razlika & $\begin{array}{l}\text { Vrednost } \\
\text { kvadrata }\end{array}$ & Frekvencija & $\begin{array}{c}\text { Značaj- } \\
\text { nost }\end{array}$ \\
\hline \multirow[t]{3}{*}{ TEA and Opportunity motive } & Between Groups & 367,706 & 2 & 183,853 & 15,043 &, 000 \\
\hline & Within Groups & 549,998 & 45 & 12,222 & & \\
\hline & Total & 917,704 & 47 & & & \\
\hline \multirow{3}{*}{$\begin{array}{l}\text { TEA and Necessity motive } \\
\text { (entr because of no better } \\
\text { choice for work) }\end{array}$} & Between Groups & 142,471 & 2 & 71,235 & 12,870 &, 000 \\
\hline & Within Groups & 249,067 & 45 & 5,535 & & \\
\hline & Total & 391,537 & 47 & & & \\
\hline \multirow[t]{3}{*}{ Ratio opportunity/necessity } & Between Groups & 178,747 & 2 & 89,374 & 15,539 &, 000 \\
\hline & Within Groups & 258,826 & 45 & 5,752 & & \\
\hline & Total & 437,573 & 47 & & & \\
\hline \multirow{3}{*}{$\begin{array}{l}\text { Non-opportunity motive: } \\
\text { necessity/maintain income }\end{array}$} & Between Groups & 2362,049 & 2 & 1181,024 & 15,243 &, 000 \\
\hline & Within Groups & 3486,547 & 45 & 77,479 & & \\
\hline & Total & 5848,596 & 47 & & & \\
\hline \multirow{3}{*}{$\begin{array}{l}\text { TEA and Improvement Driven } \\
\text { Opportunity motive }\end{array}$} & Between Groups & 2565,286 & 2 & 1282,643 & 11,111 &, 000 \\
\hline & Within Groups & 5194,934 & 45 & 115,443 & & \\
\hline & Total & 7760,221 & 47 & & & \\
\hline \multirow{3}{*}{$\begin{array}{l}\text { Exited a business in the past } \\
\text { year, business did not continue }\end{array}$} & Between Groups & 108,827 & 2 & 54,414 & 7,687 &, 001 \\
\hline & Within Groups & 318,522 & 45 & 7,078 & & \\
\hline & Total & 427,349 & 47 & & & \\
\hline \multirow[t]{3}{*}{ Working: \% involved in TEA } & Between Groups & 1959,977 & 2 & 979,989 & 19,238 &, 000 \\
\hline & Within Groups & 2292,253 & 45 & 50,939 & & \\
\hline & Total & 4252,230 & 47 & & & \\
\hline \multirow{3}{*}{$\begin{array}{l}\text { Not working: \% involved in } \\
\text { TEA }\end{array}$} & Between Groups & 178,533 & 2 & 89,266 & 7,947 & ,001 \\
\hline & Within Groups & 505,445 & 45 & 11,232 & & \\
\hline & Total & 683,978 & 47 & & & \\
\hline \multirow{3}{*}{$\begin{array}{l}\text { Graduate experience: \% } \\
\text { involved in TEA }\end{array}$} & Between Groups & 403,718 & 2 & 201,859 & 3,008 & ,068 \\
\hline & Within Groups & 1610,486 & 24 & 67,104 & & \\
\hline & Total & 2014,205 & 26 & & & \\
\hline \multirow{3}{*}{$\begin{array}{l}\text { Graduate experience: \% } \\
\text { involved in EB }\end{array}$} & Between Groups & 28,225 & 2 & 14,112 & ,260 & ,773 \\
\hline & Within Groups & 1248,104 & 23 & 54,265 & & \\
\hline & Total & 1276,329 & 25 & & & \\
\hline
\end{tabular}

Source: Calculation of authors 
With the features TEA and Opportunity motive, a statistically significant difference is perceived at the level $p<0.05$ between three groups of countries $F(2,367.706)=15.043, p=.000$. The real difference between the medium values of groups is at the level of medium expressed by means of the indicator eta square and is 0.4 . The subsequent comparison by means of the value Tukey HSD test points to that the group of countries named as Efficiency Driven Economies does not differ differently from Innovation Driven Economies in stimulating opportunity entrepreneurship.

With the features TEA and Necessity motive (entr because of no better choice for work), a statistically significant difference is perceived at the level $\mathrm{p}<0.05$ between three groups of countries $\mathrm{F}(2,142.471)=71.235, \mathrm{p}=.000$. The real difference between the medium values of groups is at the level of medium expressed by means of the indicator eta square is 0.36 . The subsequent comparison by means of Tukey HSD test point to that the group of countries named as Factor Driven Economies does not differ differently from Efficiency Driven Economies in stimulating Necessity entrepreneurship.

With the features Ration Opportunity/necessity, a statistically significant difference is established at the level $\mathrm{p}<0.05$ between three groups of countries $\mathrm{F}(2,178.747)=89.374, \mathrm{p}=.000$. The real difference between medium values of groups is at the level of medium expressed by means of the indicator eta square is 0.41 . The subsequent comparison by means of the value Turkey HSD test points to that the group of countries named as a Factor Driven Economies does not differ differently in relation to opp/nec entrepreneurship.

With the features Exited a business in the past year, business did not continue, a significant statistical difference is established at the level $\mathrm{p}<0.05$ between three groups of countries $\mathrm{F}(2,108.827)=54.414, \mathrm{p}=.001$. The real difference between medium values of groups is at the level of small significance expressed by means of the indicator eta square is 0.25 . The subsequent comparison by means of the value Turkey HSD test points to that the group of countries named as Efficiency Driven Economies does not differ differently from Driven economies in the failure of entrepreneurial projects.

With the features Working: \% involved in TEA, a statistically significant difference is established at the level $\mathrm{p}<0.05$ between three groups of countries $F(2,1959.977)=979.989, p=.000$. The real difference between the medium values of groups is at the level of medium significance expressed by means of the indicators eta square is 0.46 . The subsequent comparison by means of the value Tukey HSD test points to that all three groups of countries differ differently to this feature so the conditions of the environment determines significantly the inclusion of previously working people in Early Stage Entrepreneurial Activity. 
With the features Not working: \% involved in TEA, a statistically significant difference is established at the level $p<0.05$ between three groups of countries $F(2,178.533)=89.266, p=.001$. The real difference between the medium values of groups is at the level of small significance expressed by means of the indicator of eta square is 0.26 . The subsequent comparison by means of Tukey HSD test points to that the group of countries named as Efficiency Driven Economies does not differ significantly from Innovation Driven Economies in relation to the inclusion on previously not working people in Early Stage Entrepreneurial Activity.

At the end of this part of the analysis, we can draw a conclusion that in the bigger part, the hypothesis $\mathrm{H} 2$ is confirmed as for the power of environment relating to selected features that are directly or indirectly connected with the motives of entrepreneurial behavior.

Table 3. Correlation between Observed Variables

\begin{tabular}{|c|c|c|c|c|c|c|c|}
\hline & & $\begin{array}{l}\text { Respondents who } \\
\text { discontinued } \\
\text { business (sample) }\end{array}$ & $\begin{array}{l}\text { Exited a } \\
\text { business }\end{array}$ & $\begin{array}{l}\text { Working: } \\
\text { in TEA }\end{array}$ & $\begin{array}{l}\text { Not } \\
\text { working: } \\
\text { in TEA }\end{array}$ & $\begin{array}{l}\text { Graduate } \\
\text { in TEA }\end{array}$ & $\begin{array}{l}\text { Graduate } \\
\text { in } \mathrm{EB}\end{array}$ \\
\hline TEA and & Pearson Correlation &, $358^{*}$ &, $694^{* *}$ & $932^{* *}$ &, $778^{* *}$ & $494^{* *}$ & , 149 \\
\hline Opportunity & Sig. (2-tailed) & ,012 &, 000 &, 000 &, 000 &, 009 & ,467 \\
\hline motive & $\mathrm{N}$ & 48 & 48 & 48 & 48 & 27 & 26 \\
\hline TEA and & Pearson Correlation &, $507^{* *}$ & $836^{* *}$ & $902^{* *}$ &, $561^{* *}$ & ,328 &,- 025 \\
\hline \multirow[t]{2}{*}{ Necessity motive } & Sig. (2-tailed) &, 000 &, 000 &, 000 &, 000 &, 095 & ,904 \\
\hline & $\mathrm{N}$ & 48 & 48 & 48 & 48 & 27 & 26 \\
\hline Ratio opportunity/ & Pearson Correlation &,- 219 &,$- 315^{*}$ &,$- 365^{*}$ &,- 192 &,- 025 & ,094 \\
\hline \multirow[t]{2}{*}{ necessity } & Sig. (2-tailed) &, 134 & ,029 &, 011 & ,192 & ,902 & ,648 \\
\hline & $\mathrm{N}$ & 48 & 48 & 48 & 48 & 27 & 26 \\
\hline
\end{tabular}

Source: Calculation of authors

The results of the last segment of the analysis illustrated in Table 3 relate to the connection between the indicator of the motives of entrepreneurial projects with special attention to the ratio opp/nec and selected features being indirect relationships. The ration opp/nec is in the center of the analysis and it represents the real relationship, emphasizing the nature and the strength of connection to observed variables. From the results of a correlation matrix, we can notice the positive weak correlation without statistical significance between prevailing opportunity entrepreneurship and proportional participation of graduate 
experience: \% involved in EB) in the last stage of entrepreneurial process shown in $\mathrm{r}=.094, \mathrm{p}=0.648$ and non-important determination coefficient. Considering this relationship of the mentioned ratio and other selected features as Exited a business in past year, business did not continue/discontinued, Working: \% involved in TEA, Not working: \% involved in TEA i Graduate experience: \% involved in TEA, the negative correlation is present of different power and significance. The medium strength of negative correlation at the level of statistical significance without significant determination coefficient is present between prevailing opportunity entrepreneurship and business failure with $\mathrm{r}=-.315, \mathrm{p}=0.029$. Also, the medium strength of negative correlation at the level of statistical significance without significant determination coefficient is present between prevailing opportunity entrepreneurship and the people being employed after inclusion in entrepreneurial projects with $\mathrm{r}=-.365, \mathrm{p}=0.011$; it points to that opportunity motive is significantly the consequence of the previous business experience.

\section{Conclusion}

In conclusion, we can emphasize that the analysis of available data, observed features and selected methodology confirm, largely, expectations shown in research questions and set hypotheses, pointing to the nature of relationships of two kinds of motives of entrepreneurial projects, necessity and opportunity, as well as the big role of business ambient in shaping entrepreneurial intentions.

The analysis of prevailing motives in some stages of the entrepreneurial process dependent on the attained degree of economic development as a determinant of entrepreneurial conditions, as well as identification of potential differences between different degrees of economic development of countries classified into three groups according to in advance known methodology and selected variables that directly and indirectly show the motives of entrepreneurial projects point to a possible conclusion.

This means that in this study, we have achieved the following results:

- Correlation analysis confirms the hypothesis H1 and the logical connection in the form of negative correlation between the ratio opportunity/necessity entrepreneurship and the volume of entrepreneurial activities according to the stages of the entrepreneurial process.

- And hypothesis H1a also confirmed, in the form of positive correlation of the ratio opportunity/necessity entrepreneurship and the degree of economic development of countries measured by GDP per capita in US\$ PPP basis.

- In the ANOVA analysis hypothesis H3 is accepted. It means, there is a statistically significant difference between defined groups of countries of different development degree according to all observed variables; 
- The correlation analysis confirms hypothesis H3, there is a positive correlation between the ratio opportunity/necessity entrepreneurship of high educated entrepreneurs and the entrepreneurs who, working/active at work/being already employed, entered the entrepreneurial relationship.

The general conclusion, as well as the answer to the set theme of this work, explicitly points to the dominant and the double role of social and economic conditions in generating stimuli for entrepreneurial projects. Economic-system conditions determine the capabilities of individuals in the form of knowledge, experience and skills for recognizing business opportunities (opportunity entrepreneurship), on the one side, but also the circumstances with numerous negative powers where an individual has no possibility to choose except selfemployment (a necessity entrepreneurship), on the other side.

\section{References}

Acs, Z. J., Audretsch, D. B., Braunerhjelm, P. B., \& Carlsson, B. (2004) The Missing Link: The Knowledge Filter and Entrepreneurship in Endogenous Growth (No. 4783). CEPR Discussion Papers

Baumol, W.J. (2003) On Austrian analysis of entrepreneurship and my own, Austiran Economics and Entrepreneurial Studies, Vol 6, pp. 57-66m Amsterdam: Elsevier Science

Bertrand, Y., (1995) Contemporary theories and practice in education. (Madison, WI: Atwood Publishing)

Birch, D. (1987) "Job Creation in America", New York, Free Press

Block, J. Sandner, P., (2006) Necessity and Opportunity Entrepreneurs and their Duration in Self- employment: Evidence from German Micro Data, Journal of Industry, Competition and Trade (2009), 9(2): 117-337

Block, Jörn H., and Marcus Wagner (2010) "Necessity and opportunity entrepreneurs in Germany: Characteristics and earnings differentials." Schmalenbach Business Review, April:154-174

Boyd, N. G., \& Vozikis, G. S. (1994) The influence of self-efficacy on the development of entrepreneurial intentions and actions. Entrepreneurship Theory and Practice, 18: 63-63

Caliendo, Marco, and Alexander S. Kritikos (2009) “'I want to, but I also need to': Start-ups resulting from opportunity and necessity" IZA DP No. 4661

Corbett, A. C. (2005) Experiential learning within the process of opportunity identification and exploitation. Entrepreneurship Theory and Practice, 29(4), 473-491

Davidsson, P. (1989) Continued entrepreneurship and small firm growth. Stockholm School of Economics, The Economic Research Institute

Deli, F., (2011) Opportunity and Necessity Entrepreneurship: Local Unemployment and the Small Firm Effect, Journal of Management Policy and Practice vol. 12(4): 38-57

Drucker, P.F. (1985) Innovation \& Entrepreneurship: Practice and Principles. Harper \& Row, New York 
Fairlie, R., W. (2011) Entrepreneurship, Economic Conditions and Great Recession, University of California, Santa Cruz

Giacomin, O., Janssen, F., Guyot, J., Lohest, O. (2011) Opportunity and/or necessity entrepreneurship? The impact of the socio-economic characteristics of entrepreneurs, MPRA Paper No. 29506

Gurtoo, A. \& Williams, C.C. (2009) Entrepreneurship and the informal sector: Some lessons from India, Entrepreneurship and Innovation, 10(1): 1-8

Hessels, J., van Gelderen, M. \& Thurik, R. (2008) Entrepreneurial aspirations, motivations, and their drivers, Small Business Economics, 31(3): 323-339.

Katz, J. A. (2003) The chronology and intellectual trajectory of American entrepreneurship education: 1876-1999. Journal of business venturing, 18(2): 283-300

Kirzner, I. M. (1997) Entrepreneurial discovery and the competitive market process: An Austrian approach. Journal of economic Literature, 35(1)

Lazear, E., P., (2005) Entrepreneurship. Journal of Labor Economics, 23(4): 649-680.

Leibenstein, H. (1968) "Entrepreneurship and Development," American Economic Review, 58(2): $72-83$

Levie, J. (2006) From business plans to business shaping: Reflections on an experiential new venture creation class. WP040/2006. London, UK: National Council for Graduate Entrepreneurship

Levie, J., Autio, E., (2008) A theoretical grounding and test of the Gem model, Small Business Economics, 31 (3): 235-263

Maslow A. H. (1954) Motivation and Personality. Harper and Brothers, New York

Parker, S. C. (2006) Entrepreneurship, self-employment and the labour market.Oxford handbook of entrepreneurship, 435-460

Pelham, A. M., \& Wilson, D. T. (1995) A longitudinal study of the impact of market structure, firm structure, strategy, and market orientation culture on dimensions of small-firm performance. Journal of the academy of marketing science, 24(1): 27-43

Porter, M. E., \& Schwab, K. (2009) The Global Competitiveness Report 2008-2009. In World Economic Forum.

Preisendörfer P. and T. Voss (1990) "Organizational mortality of small firms: The effects of entrepreneurial age and human capital.” Organizational Studies, 11:107-129

Robichaud, LeBrasseur and Nagarajan (2010) "Necessity and Opportunity-driven Entrepreneurs in Canada: An Investigation into their Characteristics and an Appraisal of the Role of Gender", Journal of Applied Business and Economics.

Schumpeter, J.A. (1934) The Theory of Economic Development. Cambridge, MA: Harvard University Press

Schwab, K. (2009) Global Competitiveness Report 2009-2010. World Economic Forum. Geneva, Switzerland. ttp://www.weforum.org/pdf/GCR09/GCR20092010 fullreport.pdf

Slolomon, G., et al. (2002) The State of Entrepreneurship Education in the United States: A Nationwide Survey and Analysis, International Journal of Entrepreneurial Education, 1(1): $1-22$

Sorgman, M. and Prakison, K. (2008) The Future is now: Preparing K-12 Teachers and Students for an Entrepreneurial Society, Journal of Entrepreneurhip Education 11, $75-86$ 
Tan, J. (1996): "Regulatory Environment and Strategic Orientation in Transitional Economy", Entrepreneurship Theory and Practice

Thompson, P. (2011) Necessity and Opportunity Entrepreneurs through the Business Cycle, CIRPÉE-Ivey Conference on Macroeconomics and Entrepreneurship, Montreal, May 6-7

Van Praag, C. M. and J. S. Cramer (2001) An Estimated Equilibrium Model of Business Formation and Labor Demand by Entrepreneurs, Economica 269, 45-62

Van Praag, C. M., (1996) Determinants of Successful Entrepreneurship, Amsterdam: Thesis Publishers

Von Mises, L., \& Greaves, B. B. (1949) Human action. Liberty Fund, pp. 59-62

Wright, M., Hmieleski, K. M., Siegel, D. S., \& Ensley, M. D. (2007) The role of human capital in technological entrepreneurship. Entrepreneurship Theory and Practice, 31(6): 791-806

\section{PREDUZETNIŠTVO KAO POSLEDICA EKSTERNIH PODSTICAJA I/ILI INTERNIH POBUDA}

Apstrakt: Osnovna svrha ovog rada jeste spoznaja odnosa osnovnih preduzetničkih motiva (engl. nacessity and opportunity) u zavisnosti od opštih društvenih i preduzetničkih prilika po fazama preduzetničkog procesa. U radu su prezentovani rezultati analize odabranih varijabli predhodno pomenutih pojava na bazi podataka iz GEM projekta u 2009 godini za 48 zemalja razvrstanih u tri grupe po fazama ekonomskog razvoja. Za poređenje grupa i utvrđivanje razlika koristila se jednofaktorska analiza varijanse dok su se odnosi i veze između odabranih obeležja stepena razvoja, preduzetničkih aktivnosti i motiva preduzetničkog poduhvata analizirali pomoću Pirsonovog koeficijenta korelacije. Analizom raspoloživih podataka i odabranih obeležja potvrđena je velika zavisnost motiva preduzetničkih poduhvata i uslova okruženja različitog stepena razvijenosti koji determinišu razlike po svim posmatranim obeležjima koji su diretno ili indirektno povezani sa preduzetničkim odlukama.

Ključne reči: preduzetništvo, preduzetnički uslovi, preduzetnički proces, nužno preduzetništvo, preduzetništvo mogućnosti 